\title{
ФІЛОСОФІЯ
}

UDC 130.2:125

DOI https://doi.org/10.32837/apfs.v0i27.911

\author{
O. V. Borodenko \\ ORCID ID: https://orcid.org/0000-0002-8835-7471 \\ PhD in Philosophy, \\ Senior Lecturer at the Department of Sociology \\ Petro Mohyla Black Sea National University
}

\section{THE PROBLEM OF THE LOCAL IN PHILOSOPHICAL TRADITION AND IN MODERN PHILOSOPHY OF CULTURE}

Introduction. In our time, the problem of the local is particularly relevant. Unfortunately, the world is becoming shaky again, and the processes taking place in it are becoming more and more unpredictable. At such times - different crises, wars and transformations, people are especially inclined to think about the microcosm in which they live and which they share with their loved ones. Any local space, despite its apparent smallness and inconspicuousness, is a powerful alternative to the global world order with its consistency, hierarchy and rationalism, and often with the presence of the potential for aggressiveness towards an individual. A classic of European philosophy, Jürgen Habermas, in a recent interview, once again stated the deepening process of disintegration of the public sphere: "Based on the French model - from Zola to Sartre and Bourdieu, the public sphere is crucial to the intellectual, though its fragile structure is undergoing an accelerated process of decay" .

But what is it "local", "locality"? Does philosophy in general and philosophy of culture, in particular, need these concepts? If the answer is yes, then why, despite the fact that these concepts are quite often found in various philosophical discourses, has its meaning not yet been completely clarified?

In this article we will try to briefly trace the evolution of the concepts "local" and "locality" in classical and contemporary philosophy (using the concepts of individual thinkers as an example), and also to determine the meaning of this concept for

\footnotetext{
${ }^{1}$ Analyzing negative trends in the media space, Habermas shows how these phenomena undermine people's confidence in the sphere of publicity: "the commercialization of public attention had already triggered the disintegration of the public sphere. An example is the US and its exclusive use of private TV channels. Now, new means of communication have a much more insidious model of commercialization in which the goal is not explicitly the consumer's attention, but the economic exploitation of the user's private profile. They rob customers' personal data without their knowledge in order to manipulate them more effectively, at times even with perverse political ends, as in the recent Facebook scandal" [5].
}

understanding the contemporary cultural context ${ }^{2}$. In our opinion, the philosophical discourse, designed to comprehend the essence of the local, is most important precisely for the philosophy of culture, since the basis of culture, as is well known, are values, norms and symbols; therefore, it is very important for a modern person to compare those values, norms and symbols that have universal significance with the values, norms and symbols that form the lifeworld of an individual.

The urgency of this problem is recognized by many scientists. Here is what Peter Sloterdijk, one of the leading contemporary philosophers, says about this: "If we try to radically re-raise the question of 'where', this means that the meaning of absolute localization, and thus the basis of the distinction between big and small, comes back to modern thinking. $<\ldots>$ The question of our 'where' makes more sense than ever, for it is aimed at the place created by people to have such 'somewhere' in which they appear as who they are" [12, p. 24].

The main goal of our research is to define problem of the local as an actual cultural and philosophical problem. The tasks of our work include the following: 1) try to define "the local" as a phenomenon of philosophy and culture and highlight the main characteristics of this phenomenon; 2) to justify the need to develop problem of the local within the framework of the philosophy of culture; 3 ) to trace the brightest moments of studying the local in philosophy: from the emergence of interest in spatial issues and the first attempts to analyze certain parts of space as primary locales in ancient philosophy to the analysis of localities in contemporary philosophy of culture.

Analysis of the recent achievements. Despite the wide range and multidimensionality of research on this issue, there are three main areas of studying

The concept of "the local" has already been fixed in a number of sciences. So, in sociology and geography, the "phenomenon of the mythical space, its localities and the effect on human consciousness" is explored [2, p. 178]. 
the local as a cultural phenomenon: a) in the framework of the concepts of everyday practices and communications; b) in modern urbanism (for example, in the study of urban space); c) within the framework of globalization theories (when analyzing the "global/local" dichotomy and within the framework of the concept of glocalization).

Among the recent publications that examine the spatial aspects of everyday life, it is first necessary to pay attention to the studies of the famous Kharkov professor I. Karpenko. In his works "it is thematized on the system and conceptual level the complicated web of the intersupplementary links between the philosophical reception of the everydayness and the constitution of the philosophical space of culture" $[7, \mathrm{p} .71]$. The space of the everyday world of man is also analyzed in the works of O. Boiko, A. Heller, V. Kyzyma, V. Leleko, O. Markovtzeva, N. Novikova, K. Skliarenko, F. Tenbruck, E. Zolotukhina-Abolina, and others. The authors of most philosophical and cultural studies in this area seek to analyze the space of everyday life, to identify certain levels in it, as well as, in their opinion, the most significant loci or spheres of everyday human experience. The study of everyday practices in philosophy is closely related to the analysis of a human's life-world, which "starting from childhood is formed primarily as a communicative space" [3, p. 98].

Urban spaces as a set of localities are analyzed in philosophy and the humanities from very different perspectives: for example, as a territory of the clash of interests of various social groups, their likes and dislikes: "As contested spaces, cities display the shifting outcomes of the struggles for participation, the icons of love that the different social groups practically demonstrate for them" [11, p. 23]. Or within the concept of nomadism; so in the works of K. Cupers "nomadism does not appear in void, not in empty spaces, but in constantly modifying ones, that are permanently being produced and reproduced" [4, p. 737].

The concept of the local in the context of global space is also has been analyzed in the framework of the concept of "imaginary landscapes" by Arjun Appadurai(1996), as well asin the works of N. Brenner (2004), E. Sheppard (2002), V. Roudometof (2003), L. Pries (2005), Th. Courchene (2001), R. Sandoval (2010), W. Sites (2000) and others. When analyzing the most significant publications on this issue, it is impossible not to mention the works of A. Syrodeeva [16; 17], who explores the problem of localities in a socio-cultural context, as a "small world", which is extremely important for the formation of values and meanings of both an individual and society [17, p. 3].

Despite the fact that the problem of the local has firmly entered the list of topical philosophical problems and is being developed in various aspects, we still do not have a sufficiently clear definition of the local, as well as its place in the system of cultural values.

Presentation of the main research. Interest in the question "where" was present in European philosophy since ancient times. In the ancient Greek philosophical tradition, in particular Plato and Aristotle, the designation of the local is primarily an attempt to streamline the phenomena of the world, which is caused by the desire to overcome chaos, to explain the world, to separate true knowledge from false, being from non-existence. It can be argued that the local discourse already in the works of Plato has ontological significance.

So, in the dialogue of Plato Sophist [10] proclaimed the postulate that the cosmos is an ordered whole; therefore, for any person, it is important first of all to take care of the ordering of your soul and your microcosm. Only in this way can one come closer to the ideal foundation of being (Soph. 228b-228d). At the same time, Plato disagrees with philosophers who consider being to be one and indivisible (Soph. $245 \mathrm{a}-245 \mathrm{~b}$ ). Being is mixed, consisting of a set of both moving and static elements (Soph. 249a). Plato applies the "method of mixing" in his ontology, ethics and aesthetics. The idea of the good is also based on this method. Moreover, the mixing of the elements of the universe does not resemble chaos; on the contrary, mixing for Plato is harmonious, has measure and proportion (Phileb. 64d-64e) [9]. Mixing implies a separation. Having recognized this, a philosopher can proceed to the mental isolation of various elements of being, various loci with the analysis of them.

Problems of the local were considered in classical philosophy, being an integral part of the problems of space and time. We would like to concentrate on those aspects that are directly related to the destruction of the usual structure of culture, which has been formed since the Enlightenment, and which consists of elite, mass and popular culture.

According to J. Baudrillard, the culture of the end of the twentieth century has embarked on the path of infinite and fruitless self-reproduction. This process is caused by the crisis of values $[1, p .6]$. In a situation of crisis of universal values, the desire to search for alternatives, values not of a universal, but of a local character, awakens. One of the manifestations of such a search can be considered the philosophical postmodern with its pronounced refusal to fix the "fundamental" methods and forms of discourse building, the rejection of hierarchies of various kinds (which was traced in modernism), from the metadiscourse and metanarratives, the transition from forms to "antiforms" as an attempt to demonstrate the principle of separation/disclosure, from modernist centering to scattering, from paradigm to syntagma, from transcendence to immanence [6, p. 586-593]. In this connection, the current cultural situation is 
interpreted as "headstand" (Kopfüber), somersaults (Flip-flop) [18, p. 38], "polarity reversal" (Umpolung), $[18$, p. 76$]$, or as "the culture turned inside out" (Umgekehrt) [18, p. 163].

According to J.F. Lyotard, the determining factor for the postmodern situation is incredulity toward metanarratives [8, p. xxiv]. Metanarratives "is a global or totalizing cultural narrative schema which orders and explains knowledge and experience" $[15, \mathrm{p} .4]$. The decline of metanarratives implies the refusal to fix "obligatory", "fundamental" forms of discourse, mega-discursiveness in general, paradigmatic topics that have dominated culture for a long time (such as freedom and democracy, the concept of tolerance, people as a cognitive subject, people as a social subject, feminism, etc.). Metanarrativas, which constitute the "dominant code" of any cultural tradition, unexpectedly yield in postculture a place to local narratives with their accentrism, pluralism and pronounced antiparadigmity.

The term "indetermanence" proposed by I. Hassan to define the essence of the postmodern situation and used "to designate two central, constitutive tendencies in postmodernism: one of indeterminancy, the other of immanence" [6, p. 589], in our opinion, most fully reveals the postmodern abandonment of hierarchical structuring of culture and the process of transition from centering to scattering, to the peripheral location of cultural objects and phenomena. The principle of "indetermanence" can be considered, in our opinion, a kind of "methodological basis" of locality as a phenomenon of culture. I. Hassan interprets indeterminancy as "a complex object that can be described using such various concepts as ambiguity, fragmentaryness, dissent, pluralism, arbitrariness, rebellion, distortion, deformation" [6, p. 590]. "Hermeneutics of uncertainty", in our opinion, defines any cultural locality (the space of a book or film, the loci of everyday life or the cultural space of a person/family/group/nation, or, for example, the symbolic space of a city).

Indeed, cultural locality is difficult to fix, it seems to "resist" to any research and researcher, trying to "escape" from analysis. Very often, one locality "hides" inside another, more extensive (for example, there are many local islets within the space of a megalopolis, and within each culture there are various subcultures and internal cultural movements, etc.). Each locality as a cultural phenomenon, besides this, is emphasized pluralistic, which follows from its symbolic nature, from the versatility of its symbolic content.

There are other directions in the study of the problem of locality and localization in contemporary philosophy. One of the most interesting, as it seems to us, is the microspherology of the German thinker Peter Sloterdijk [12; 13; 14]. Building his concept of geometric vitalism, he proceeds from the thesis that "any solidarization is the formation of a certain sphere, that is, the creation of a certain internal space" $[12$, p. 10]. Early spatial experience plays a crucial defining role in our lives. It is human nature to transfer this experience "to new places and primary movements, to remote arenas. The boundaries of my transference ability are the boundaries of my world" [12, p. 10]. Sloterdijk called the microworlds in which a person lives, "spheres" $[12$, p. 24]. A sphere is a locality in which bodily sensations, sounds, smells and colors, as well as close interpersonal communication between people inhabiting this space, take on special significance. The key role in the formation of a person is played by the very first sphere, the mother's womb.

Conclusions. The concept of "locality" is now part of the thesaurus of many disciplines. At the same time, in philosophy this concept is found in various contexts, its meaning is currently not defined more or less precisely. The problem of the local, in our opinion, is an urgent philosophical problem. Its relevance is primarily explained by the fact that in the modern globalized world, a person needs to "take root", looks for ways to strengthen his own life principles, and demonstrates the need to preserve his values and interests, his life-world, which is now more vulnerable than ever before. In other words, as P. Sloterdijk notes, "the meaning of absolute localization, and thus the basis of the distinction between big and small, comes back to modern thinking".

The question of where, that is, the question of the location of the object in space and time interested philosophers from ancient times. Thus, in ancient philosophy, the problem of the local has ontological and epistemological significance, since the formulation of this problem is designed to separate being from non-being, true knowledge from false. In an effort to comprehend the essence of the universe and the basic principles of world order, ancient philosophy takes as its basis the postulate that the cosmos, in contrast to chaos as an unordered whole, is a mixture, a collection of a great many diverse elements, each of which has its own place in space.

In contemporary philosophy, the most promising problem, in our opinion, is the study of the problem of localities primarily in cultural and philosophical terms. This problem is interdisciplinary in nature. In the humanities, locality is currently analyzed primarily in the framework of concepts of everyday practice and communication, in urban space research, and also in the framework of cultural globalization theories (for example, in studying the global localization phenomenon).

Analysis of the most important philosophical and cultural studies on this issue, as well as analysis of 
recent publications, allows us to identify the main characteristics of locality as a cultural phenomenon, namely: a) attachment to a particular place (locus), the presence of "address"; b) locality is at the same time a fragment of the world and a holistic microworld, living by its own laws; c) locality exists in space and time, it is chronotopic; d) dynamic and historic; each locality has its own "biography"; f) any locality is created by people, it is an anthropological phenomenon, like culture as a whole; f) locality as a cultural phenomenon is symbolic.

Thus, locality considered asacultural phenomenon is a kind of holistic microcosm (microsphere) formed by a person or a group of people as part of his (their) life world and accumulating key values, ideas, symbols, etc., which are especially significant for these people in a certain area of human life and culture.

\section{References}

1. Baudrillard J. The Transparency of Evil. Translated by J. Benedict. London - New York : Verso, 1993. $183 \mathrm{p}$.

2. Borodenko 0. New Mythology of Space : The Symbolization of The Local [Novyie mifologii prostranstva : simvolizatsiya lokalnogo]. Hileya : scientific bulletin. Vol. 137 (No. 10). Kyiv: Vydavnytstvo "Hileya", 2018. P. 176-179 [in Russian].

3. Borodenko O. The Life-World of a Child In Andrei Platonov [Zhyttievyi svit dytyny u Andriia Platonova]. Humanitarni studii [Humanitarni studii : Zbirnyk naukovykh prats Kyivskoho natsionalnoho universytetu imeni T.H. Shevchenka]. 2011. № 9. P. 95-104 [in Ukrainian].

4. Cupers K. Towards a Nomadic Geography: Rethinking Space and Identity for the Potentials of Progressive Politics in the Contemporary City. International Journal of Urban and Regional Research. 2005. Vol. 29 (No. 4). P. 729-739.

5. Habermas J. "For God's Sake, Spare Us Governing Philosophers!". Interview with El Pais Semana. 2018. May 7. URL: https://elpais.com/elpais/2018/05/07/ inenglish/1525683618_145760.html.

6. Hassan I. Toward a Concept of Postmodernism. Postmodern American Poetry: A Norton Anthology / ed. P. Geyh. New York : Norton, 1997. P. 586-593.

7. Karpenko I. Philosophy and the world of everyday life [Filosofiia i svit povsiakdennosti]. Filosofski obrii. 2009. № 22. P. 59-72 [In Ukrainian].

8. Lyotard J.-F. The Postmodern Condition. A Report On Knowledge. Translation by G. Bennington, B. Massumi. Manchester : Manchester University Press, 1984. $138 \mathrm{p}$.

9. Plato. Philebus [transl. Harold North Fowler]. Plato in Twelve Volumes. Vol. 8. Loeb Classical Library. Cambridge, MA : Harvard, 1925.

10. Plato. Sophist. With Translation, Introduction and Glossary by Eva Brann, Peter Kalkavage, Eric Salem. Newburyport: Focus Publishing, 1925.93 p.

11. Ruggiero V. Movements in the City. Conflict in the European Metropolis. Harlow : Pearson Education, 2001.
12.Sloterdijk P. Bubbles: Spheres. Volume I : Microspherology / translation by W. Hoban. Los Angeles : Semiotext(e), 2011. $664 \mathrm{p}$.

13. Sloterdijk P. Globes: Spheres. Vol. II : Macrospherology / translation by W. Hoban. Los Angeles: Semiotext(e), 2014. $1024 \mathrm{p}$.

14. Sloterdijk P. Foams : Spheres. Volume III : Plural Spherology / translation by W. Hoban. Los Angeles : Semiotext(e), 2016.912 p.

15. Stephens J., McCallum R. Retelling Stories, Framing Culture: Traditional Story and Metanarratives in Children's Literature. New York : Garland Pub, 1998. $316 \mathrm{p}$.

16. Syrodeeva A. Locality and contemporaries [Lokalnost i sovremenniki]. Kollazh-2. Moscow : IF RAN, 1999. P. 7-17 [In Russian].

17. Syrodeeva A. The world of small things. Experience describing locality. [Mir malogo. Opyit opisaniya lokalnosti]. Moscow : IF RAN, 1998. 124 p. [in Russian].

18. Traeger J. Kopfüber. Kunst am Ende des 20. Jahrhunderts. München : C.H. Beck Verlag, 2004. $191 \mathrm{~s}$.

\section{Summary}

Borodenko $O$. $V$. The problem of the local in philosophical tradition and in modern philosophy of culture. - Article.

The present article is concerned with the problem of the local in the history of philosophy and in contemporary philosophy of culture. It emphasizes the relevance and interdisciplinary essence of this problem. The evolution of the concepts "local" and "locality" in classical and contemporary philosophy (by the example of the concepts of individual thinkers) is traced, and the meaning of these concepts for understanding the contemporary cultural context is determined. So, in particular, the development of ideas about the localization of an object in space in ancient philosophy (in Plato) is traced. The problem of the local in non-classical and post-non-classical philosophy is considered in connection with the problem of the crisis of cultural values. An attempt is made to define the concept of "locality" as a cultural phenomenon based on the analysis of the works of P. Sloterdijk, I. Hassan, J. Baudrillard and others, as well as the latest scientific publications. Emphasis is placed on analyzing the problem of the local as a philosophical concept, and at the same time, the phenomenon of culture, in the framework of postmodern ideas, the theory of cultural globalization, in the microspherology of P. Sloterdijk. The principle of "indetermanence" by I. Hassan, which most fully reveals the postmodern rejection of hierarchical structuring of culture and the process of transition from centering to scattering, to peripheral dislocation of cultural objects and phenomena, is considered as a kind of "methodological basis" of the analysis of locality as a cultural phenomenon.

Locality is defined by the author of the article as "a certain holistic microworld (microsphere) formed by a person or a group of people as part of his (their) lifeworld and accumulating key values, ideas, symbols, etc., that are particularly significant for these people". The main features of locality as a cultural phenomenon are considered: a) attachment to a particular place (locus); b) locality is at the same time a fragment of the world, the cosmos and a holistic microworld that lives by its 
own laws; c) spatiality and temporality, chronotopicity; d) dynamic and historic; e) anthropological, centered around a person or a group of people; f) symbolism.

Key words: philosophy of culture, locality, localization, the problem of the local in philosophy, microsphere, indetermanence.

\section{Анотація}

Бороденко О. В. Проблема локального у філософській традиції та в сучасній філософії культури. Стаття.

У статті розглядається проблема локального в історії філософії і в сучасній філософії культури. Підкреслюються актуальність і міждисциплінарний характер цієї проблематики. Простежується еволюція концептів «локальне» $\mathrm{i}$ «локальність» у класичній і сучасній філософії (на прикладі концепцій окремих мислителів), а також визначається значення цих понять для осмислення сучасного культурного контексту. Так, зокрема, простежується розвиток уявлень про локалізацію об'єкта в просторі в античній філософії (у Платона). Проблема локального в некласичній і постнекласичній філософії розглядається в контексті кризи культурних цінностей. На основі аналізу робіт П. Слотердайка, І. Хассана, Ж. Бодріяра та інших, а також останніх наукових публікацій робиться спроба дати визначення поняття «локальність» як культурного феномена. Акцентується увага на аналізі пробле- ми локального як філософського концепту, а також як феномена культури в рамках постмодерністських концепцій, теорії культурної глобалізації, в мікросферологіі П. Слотердайка. Принцип "indetermanence” I. Хассана, який найбільш повно розкриває постмодерністську відмову від ієрархічного структурування культури і процес переходу від центрування до «розкидання», до периферійної дислокації культурних об’єктів і явищ, розглядається як так зване методологічне підгрунтя локальності як феномена культури.

Локальність визначається автором статті як «певний цілісний мікросвіт (мікросфера), що утворений людиною або групою людей як частина його (ix) життєвого світу і який акумулює ключові, особливо значущі для людей цінності, ідеї, уявлення, символи тощо у певній сфері людської життєдіяльності». Розглядаються основні характеристики локальності як культурного явища, а саме належність до певного місця (локуса); фрагментарний характер (локальність - це фрагмент світу, космосу і цілісний мікросвіт, що живе за своїми законами); просторово-часовий характер, хронотопічність; динамічність та історичність; антропологічність, тобто центрованість навколо людини або групи людей; символічний характер.

Ключові слова: філософія культури, локальність, локалізація, проблема локального у філософії, мікроcфepa, "indetermanence". 